\title{
Effect of oromotor exercises on feeding in children with cerebral palsy: systematic review
}

\author{
Rania El Nagar ${ }^{1 *}$ (D), Alaa AL-Nemr² and Faten Abdelazeim²
}

\begin{abstract}
Background: Feeding problems are prevalent in children with cerebral palsy (CP). Oromotor exercises (OME) should be started as soon as possible to enhance chewing and drooling. Oromotor exercises consist of active exercises, passive exercises, and sensory stimulation. The purpose of this review is to evaluate the effectiveness of oromotor exercises on feeding, chewing, and drooling in children with CP.

Body: The American Academy for Cerebral Palsy and Developmental Medicine and Preferred Reporting Items for Systematic Reviews and Meta-Analyses methodology were used to conduct a systematic review. Four databases (PubMed, Cochrane Library, PEDro, and Google Scholar) were searched; this review includes seven articles, participants were 173 participants ranging in age from 18 months to 18 years. Articles were assessed according to their level of evidence and quality assessment was done by AACPDM, PEDro scale, and JBI scale. Due to the heterogeneity across included studies, descriptive analysis was performed on all of them. Primary outcomes were chewing and drooling. Results showed the effectiveness of OME in improving drooling, but with weak evidence while not effective in improving chewing.
\end{abstract}

Conclusion: High-quality studies are required to develop a firm judgment on the influence of oromotor exercises on feeding. The current level of evidence to support the effectiveness of oromotor exercises in children with CP is currently insufficient.

Keywords: Cerebral palsy, Oral motor exercises, Oromotor exercises, Systematic review, Oral sensorimotor, Chewing, Drooling

\section{Background}

A Systematic review is a "study of studies". In order to assess the overall evidence for an intervention, all relevant research is analyzed [1]. A systematic review is a method for systematically identifying all studies on a certain research subject, appraise the studies' methodologies, describe the results, present the most important discoveries, and identify in a systematic review; all judgments used to compile information are designed to be explicit, allowing the reader to judge the quality of the

\footnotetext{
* Correspondence: Raniafaried010@gmail.com

1 Berket El Sabaa Hospital, Birket El Sab, Egypt

Full list of author information is available at the end of the article
}

review process and the possibility for bias for him or herself [1].

Cerebral palsy is a nonprogressive neuromotor disorder which has an effect on the brain [2]. A common misperception is that $\mathrm{CP}$ only develops because of an accident during delivery. $\mathrm{CP}$, on the other hand, can occur prenatally or early postnatally and be caused by a variety of factors such as hypoxia, asphyxia, intrauterine infection, intrauterine brain abnormalities, and fetal stroke [3].

Cerebral palsy is a brain developmental condition that causes movement and posture problems. It can impact oral motor abilities, causing speech delay, drooling, sucking difficulties, swallowing, and biting [4]. Oral motor

\section{Springer Open}

(๑) The Author(s). 2021 Open Access This article is licensed under a Creative Commons Attribution 4.0 International License, which permits use, sharing, adaptation, distribution and reproduction in any medium or format, as long as you give appropriate credit to the original author(s) and the source, provide a link to the Creative Commons licence, and indicate if changes were made. The images or other third party material in this article are included in the article's Creative Commons licence, unless indicated otherwise in a credit line to the material. If material is not included in the article's Creative Commons licence and your intended use is not permitted by statutory regulation or exceeds the permitted use, you will need to obtain permission directly from the copyright holder. To view a copy of this licence, visit http://creativecommons.org/licenses/by/4.0/. 
dysfunction that persists causes feeding difficulties, which leads to growth and development retardation [5]. Drooling, on the other hand, has a negative impact on social development and creates physical problems [6]. Children with $\mathrm{CP}$ have changes in their oral functions, which make feeding difficult and can lead to major health problems like malnutrition and pneumonia [7].

One of the elements affecting children's health is feeding efficiency. Feeding problems are prevalent in children with cerebral palsy, resulting in insufficient caloric intake and eventually malnutrition [8]. In children with moderate to severe $\mathrm{CP}$, feeding difficulties are common accompanied with poor feeding status and poor health [9].

Pediatric feeding disorder (PFD) is defined as a lack of age-appropriate oral intake that is linked to medical, nutritional, feeding skill, and/or psychosocial problems [10]. Up to $25 \%$ of all children have feeding problems or dysphagia; prematurely born infants had a $40 \%$ chance of having swallowing problems, a $64-78 \%$ chance of having developmental problems, and a $99 \%$ chance of having $\mathrm{CP}$ [11].

Feeding problems and poor nutritional status are frequent in children with $\mathrm{CP}$, especially as their gross motor impairment and age increase, and they may have an adverse effect on their health, physical development, and cognitive development [12]. Choking with food (56\%), feeding duration more than $3 \mathrm{~h}$ per day (28\%), frequent biting (22\%), and chewing difficulty $(26 \%)$ are all common feeding problems in children with CP [13].

Chewing is described as a rhythmic oral motor activity for communicating and softening solid food as part of the feeding process [14]. Food transportation from the front of the mouth to the molar area, where it is processed through several masticatory cycles, is the most affected aspect of chewing in patients with $\mathrm{CP}$ due to insufficient lateral and rotational tongue motions [15]. Drooling is an uncontrolled expulsion of saliva from the mouth that is frequent in children with CP [16]. Furthermore, these disorders can lead to a variety of health problems, including poor nutritional status and growth, reactive airway disease, and aspiration pneumonia [17].

Active exercises, passive exercises, and sensory applications are the three primary types of OME employed in clinical practice [18]. Active range of motion, stretching, and strength training are examples of active exercises; through the recruitment of new motor units as muscle fibers are expanded, strength, endurance, and power are all developed through these exercises [19].. Passive exercises include passive range of motion exercises, in which the movement is performed partially or wholly by the therapist or caregiver, with little or no participation from the person getting therapy. Sensory input is provided, circulation is improved, and joint flexibility is maintained or improved using these techniques [20]. The application of cold, heat, electrical stimulation, high-frequency vibration, or other agents to muscle tissues is referred to as sensory applications. Kumar et al. [21] reported a significant improvement in drooling and chewing after OME in children.

Despite the fact that there are numerous management alternatives, only a handful have been explored, including OME for drooling, there is not enough research to know how OMEs affect swallowing [22]. Arvedson et al. [22] in their systematic review recommended further research due to the dearth of studies with enough data keeping in view the stressful and socially isolating effects of drooling [22]. Three studies were taken from the systematic review of Arvedson et al. and new four studies were added to them. The purpose of this review is to examine the present research's quality of OME effectiveness on chewing and drooling in children with $\mathrm{CP}$. There is an urgent demand for high-quality studies.

\section{Main text \\ Methods}

To find relevant published studies, we used PubMed, Cochrane Library, PEDro, and Google Scholar. The following keywords were used to search those databases: $\mathrm{CP}$, Oral motor exercises, OME, Systematic Review, Oral sensorimotor, Chewing, and Drooling. This systematic review was carried out according to the criteria included in Cochrane Handbook for Systematic Reviews of Interventions [23], American Academy for Cerebral Palsy and Developmental Medicine (AACPDM) methodology for developing systematic reviews of treatment interventions [24], and Preferred Reporting Items for Systematic Reviews (PRISMA) guidelines [25].

\section{Eligibility criteria}

Studies that matched the criteria listed below were considered eligible:

\section{Study design}

Published all study designs studying the effect of OME in children with cerebral palsy except bench research, common sense/anecdotes, expert opinion, case study or report, non-randomized controlled $\mathrm{AB}$ single-subject research design (SSRD), and review articles. In this systematic review, two studies were randomized control trials $[26,27]$, three studies were quasi-experimental $[16,28$, $29]$ and two studies were case series [30,31].

\section{Participants}

This systematic review concerned children with the following inclusion criteria: $\mathrm{CP}$, aged between 18 months and 18 years. No study determined the type of $\mathrm{CP}$ except two case series studies [30,31]. One study: subject 1 was 
spastic diplegia, subject 2 was spastic quadriplegia [30]. Other study: subject 1 was spastic $\mathrm{CP}$, subject 2 was athetoid CP [31].

\section{Type of intervention}

Oromotor exercises in the form of active exercises, passive exercises, and sensory stimulation, duration between 10 days and 9 months.

Outcomes: Chewing (performance) and drooling (severity, frequency, weight of saliva, and percentage of drooling).

Language: Full-text articles are available in English.

\section{Exclusion criteria}

Studies were excluded if they were: review studies, bench research, common sense/anecdotes, expert opinion, case study or report and non-randomized controlled $A B$ SSRD, studies on children other than CP, studies that measured outcomes unrelated to the study's objectives, unpublished studies, studies published in a language other than English, and studies that combined OME with other types of modalities.

\section{Search methods for identification of studies}

References were searched from 1980 up to December 2020, using the following electronic databases: PubMed, Google Scholar, the Cochrane Library, and PEDro. Search terms used the following keywords "oral motor exercises," "cerebral palsy," "OME," "oral sensorimotor," "chewing," and "drooling" and using Boolean operators AND/OR. To find the relevant research, the titles and abstracts were checked against the inclusion and exclusion criteria. When the abstract revealed eligible study, the full text was obtained for complete assessment.

\section{Treatment procedures}

The articles discussed OME's impact on chewing and drooling in children with CP; participants received OME as a control group in three studies [26-28], and as a study group of four studies [16, 29-31].

Exercises included traditional oral motor exercises which include active and passive exercises of the tongue and lips [26, 27]; blowing candle; blowing balloons; blowing bubbles; sucking games [28]; techniques for sensory stimulation: face massage, tapping, stroking, brushing, and ice stimulation [29]; oral facilitation techniques [30]; oral motor stimulation then vibration [31]; and muscle vibration [16].

\section{Data extraction and analysis}

Data was extracted by two authors RF and AF and the third $\mathrm{FH}$ was consultant, according to data extraction form developed by AACPDM Treatment Outcomes Committee version 2008 [24]. Data was extracted according to the following items from the included articles: (1) the author and year of publication; (2) population information, including the numbers of children participating, their diagnosis, and their ages; (3) study design; (4) methodology, including the type of intervention, technique of its application, and its duration; (5) measured outcomes; and (6) results.

\section{Level of evidence}

The level of evidence of group design studies was scored according to Sacket et al. [32] and the level of evidence for the single-subject design was scored according to Logan et al. [33].

\section{Assessment of methodological quality}

Quality assessment conducted by AACPDM [24] for studies of levels I, II, and III [26, 27], Physiotherapy Evidence Database (PEDro) scale [34] for randomized controlled trials [26, 27], and Joanna Briggs Institute (JBI) scales [35,36] for all studies [26-31] and [16] through answering questions. Risk of bias was performed according to Cochrane Handbook for systematic reviews of interventions [23].

\section{Results}

After searching, 2437 articles were found (Fig. 1). PubMed recorded 326, PEDro recorded 7, Cochrane Library recorded 29, and Google Scholar recorded 2080. After removing duplicates, the records were 1284 studies. The records screened were 1284 while 1265 were excluded from abstract, then 19 full-text articles were assessed for their eligibility. Tweleve articles were excluded for various reasons because of different interventions, the children's diagnosis was not $\mathrm{CP}$, or not the same outcome; finally, seven articles were included in this systematic review.

\section{Characteristics of studies}

Data was compared and findings were represented after extracting data from each study included in this systematic review. The variation among studies with regard to outcome measures, interventions, and methodological quality of the studies did not allow us to perform a quantitative analysis (meta-analysis). The existing data was not homogenous, so the current studies were analyzed by using descriptive analysis. Included studies are presented in Table 1.

\section{Intervention}

In this systematic review, oromotor exercises were defined broadly and a variety of interventions were examined as discussed before in the treatment procedure. 


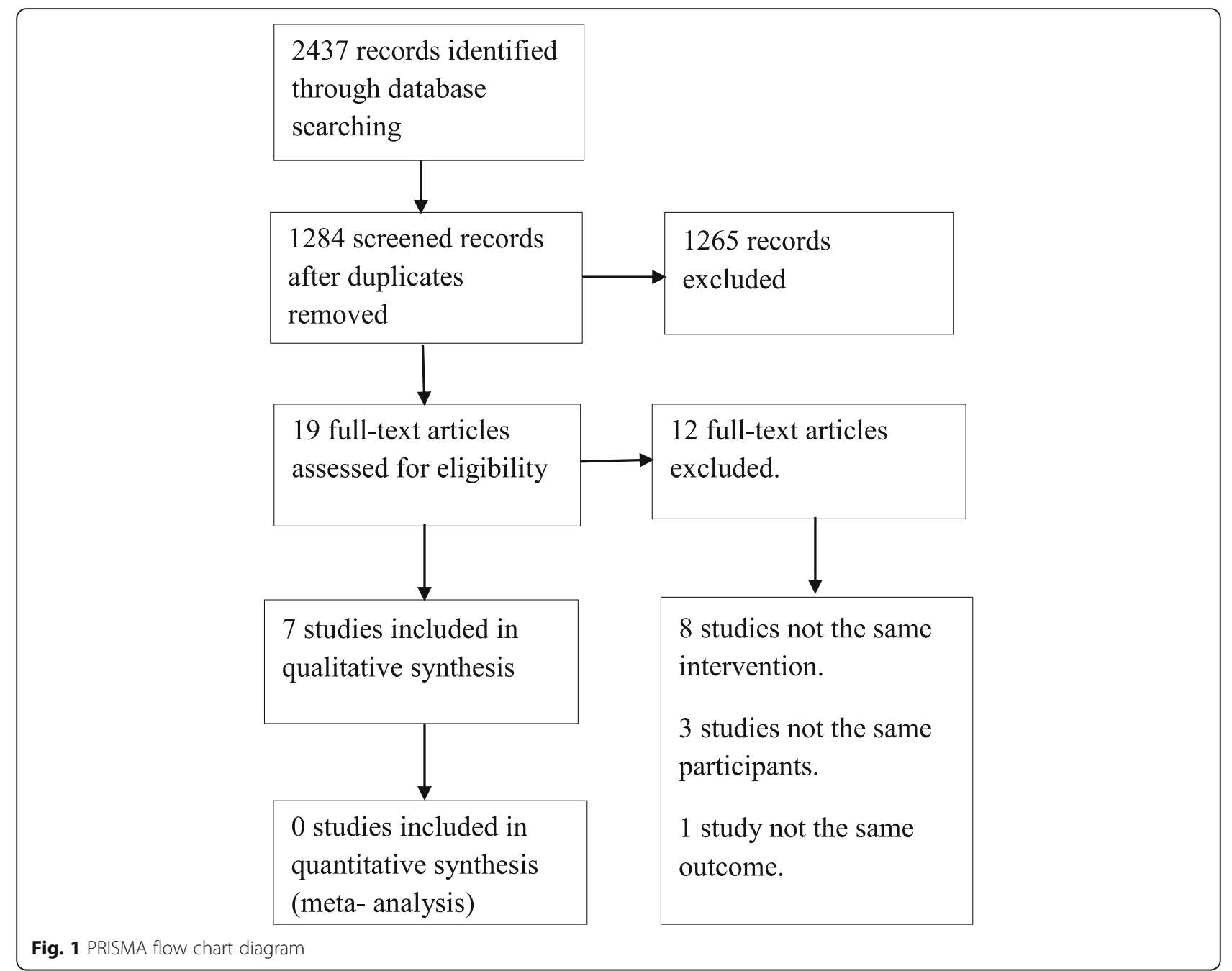

\section{Comparators}

Two studies applied Functional Chewing Training (FuCT) in the form of positioning the child, positioning the food, sensory stimulation, chewing exercises, and adjustment of food consistency [26, 27] and one study applied OME in addition to chin cup, and another group with no treatment applied [28]. There were no other comparators because other studies were of a singlesubject research design [16, 29-31].

\section{Types of outcomes measured}

Although chewing and drooling were the outcomes in the present systematic review, other outcomes were measured in studies that were included, for example, feeding behaviors [26], tongue thrust severity [27], and speech [30]. Chewing was the outcome of two articles (randomized controlled trials) [26, 27] and drooling was the outcome of six articles [27-31] and [16].

\section{Measurement of chewing and drooling}

In the present systematic review, chewing was measured by the Karaduman Chewing Performance Scale [26, 27]. Drooling was measured by drooling severity and frequency scale, drooling impact scale, visual analogue scale, and drooling quotient [16], an OHAUS 700 series triple balance [30], momentary time sampling procedure [31], scales which weigh to the nearest $1 \mathrm{~g}$ [28], and drooling severity and frequency scale [27, 29].

\section{Level of methodological quality}

Table 2 shows the results of each study on the AACP DM. Both studies scored 6 [26, 27]. The PEDro scale score for each study is shown in Table 3; one study had a score of 8 [26] and the other study was given a score of 5 [27]. Tables 4, 5, and 6 provide the results of all studies on the JBI scale. The score of randomized studies is presented in Table 4; one study obtained a score of 11 [26] and the other study had a score of 8 [27]. The score of quasi-experimental studies is presented in Table 5; 
Table 1 Summarizes the characteristics of included studies

\begin{tabular}{|c|c|c|c|c|c|c|}
\hline \multirow[t]{2}{*}{ Study } & \multirow{2}{*}{$\begin{array}{l}\text { Level of } \\
\text { evidence, } \\
\text { study } \\
\text { design }\end{array}$} & \multirow[t]{2}{*}{ Participants } & \multicolumn{2}{|l|}{ Intervention } & \multirow{2}{*}{$\begin{array}{l}\text { Outcome of } \\
\text { interest }\end{array}$} & \multirow[t]{2}{*}{ Results } \\
\hline & & & Treatment & Control & & \\
\hline $\begin{array}{l}\text { Serel Arslan } \\
\text { et al. [26] }\end{array}$ & ॥ (RCT) & $\begin{array}{l}80 \mathrm{CP}: 50 \text { in } \\
\text { treatment group, } 30 \\
\text { in control group } \\
\text { (mean age } 3.5 \pm 1.9 \\
\text { years) }\end{array}$ & $\begin{array}{l}\text { Children received } \\
\text { Functional Chewing } \\
\text { Training. It was } \\
\text { conducted five times a } \\
\text { day and five times a } \\
\text { week over a period of } 12 \\
\text { weeks }\end{array}$ & $\begin{array}{l}\text { Traditional oral motor } \\
\text { exercises were given to } \\
\text { the control group. Over } \\
\text { a period of } 12 \text { weeks, it } \\
\text { was conducted five } \\
\text { times a day, } 5 \text { days a } \\
\text { week }\end{array}$ & $\begin{array}{l}\text { - Chewing } \\
\text { function by } \\
\text { (KCPS) } \\
\text { - Feeding } \\
\text { behaviors by } \\
\text { (BPFAS) }\end{array}$ & $\begin{array}{l}\text { - The FUCT group } \\
\text { showed a significant } \\
\text { improvement }(p<.001) \text {; } \\
\text { however, the control } \\
\text { group showed no } \\
\text { change }(p=0.07) \text {. } \\
\text { - All 8BPFAS parameters } \\
\text { improved significantly } \\
\text { in the FUCT group }(p< \\
001), \text { while four BPFAS } \\
\text { parameters improved } \\
\text { significantly in the } \\
\text { control group }(p=0.02 \text {, } \\
p=.03, p=.02, p= \\
.01) .\end{array}$ \\
\hline $\begin{array}{l}\text { Inal et al. } \\
\text { [27] }\end{array}$ & ॥ (RCT) & $\begin{array}{l}32 \text { CP: } 16 \text { in the study } \\
\text { group, } 16 \text { in the } \\
\text { control group ( } 4 \text { to } 6 \\
\text { years) }\end{array}$ & $\begin{array}{l}\text { The intervention group } \\
\text { received the FUCT. It was } \\
\text { performed } 5 \text { sets ( } 1 \text { set }= \\
20 \text { min) each day over a } \\
\text { period of } 12 \text { weeks }\end{array}$ & $\begin{array}{l}\text { Children received } \\
\text { classical oral motor } \\
\text { exercise program. } \\
\text { It was performed } 5 \text { sets } \\
\text { ( } 1 \text { set }=20 \text { min) each } \\
\text { day over a period of } 12 \\
\text { weeks }\end{array}$ & $\begin{array}{l}\text { - Tongue } \\
\text { thrust } \\
\text { severity by } \\
\text { (TTRS) } \\
\text { - Drooling } \\
\text { severity and } \\
\text { frequency by } \\
\text { (DSFS) } \\
\text { - Chewing } \\
\text { performance } \\
\text { by (KCPS) }\end{array}$ & $\begin{array}{l}\text { Chewing performance ( } p \\
=0.001) \text {, tongue thrust } \\
\text { severity }(p=0.046) \text { and } \\
\text { drooling severity ( } p= \\
0.002 \text { ) all improved in the } \\
\text { FUCT group, while } \\
\text { drooling frequency ( } p= \\
\text { 0.082) remained } \\
\text { unchanged. The control } \\
\text { group showed no } \\
\text { improvement in chewing } \\
\text { performance, tongue } \\
\text { thrust, drooling severity, } \\
\text { and frequency. }\end{array}$ \\
\hline $\begin{array}{l}\text { Harris and } \\
\text { Dignam } \\
\text { [28] }\end{array}$ & $\begin{array}{l}\text { IV (Non- } \\
\text { randomized } \\
\text { quasi- } \\
\text { experimental } \\
\text { design) }\end{array}$ & $\begin{array}{l}20 \text { CP ages: group } 1 \\
\text { from } 8 \text { to } 15 \text { years, } \\
\text { group } 2 \text { from } 11 \text { to } \\
18 \text { years, group } 3 \\
\text { from } 6 \text { to } 8 \text { years, } \\
\text { and group } 4 \text { from } 6 \\
\text { to } 9 \text { years }\end{array}$ & $\begin{array}{l}\text { The program was } \\
\text { followed by group } 1 \text { for } \\
14 \text { months. They wore } \\
\text { chin cups for the first six } \\
\text { months, then continued } \\
\text { in the droolers' classes. } \\
\text { Group } 2 \text { followed the } \\
\text { program for } 11 \text { months. } \\
\text { They wore chin cups for } \\
\text { the first three months, } \\
\text { then continued in } \\
\text { droolers' classes. }\end{array}$ & $\begin{array}{l}\text { Group } 3 \text { was a 9-month } \\
\text { participant in the pro- } \\
\text { gram. They did not wear } \\
\text { chin cups, but attended } \\
\text { droolers' classes. A fourth } \\
\text { group served as controls, } \\
\text { i.e. They did not wear } \\
\text { chin cups or go to droo- } \\
\text { lers' classes. }\end{array}$ & $\begin{array}{l}\text { Drooling by } \\
\text { Scales which } \\
\text { weigh to the } \\
\text { nearest } 0.1 \mathrm{~g}\end{array}$ & $\begin{array}{l}\text { Improvement in group } 1 \\
\text { was88 percent, } \\
\text { improvement in group } 2 \\
\text { was } 75 \text { percent, } \\
\text { improvement in group } 3 \\
\text { was } 28 \text { percent and } \\
\text { group } 4 \text { had no } \\
\text { improvement nor } \\
\text { worsening. }\end{array}$ \\
\hline $\begin{array}{l}\text { Fatima } \\
\text { et al. [29] }\end{array}$ & $\begin{array}{l}\text { IV } \\
\text { (Withdrawal } \\
\text { design) }\end{array}$ & 15 CP (4 to 15 years) & $\begin{array}{l}\text { Oral motor exercises, } \\
\text { with a } 24-h \text { gap between } \\
\text { two sessions and each } \\
\text { session conducted for } 30 \\
\text { min over a period of } 6 \\
\text { months. }\end{array}$ & & $\begin{array}{l}\text { Drooling by } \\
\text { (DSFS) }\end{array}$ & $\begin{array}{l}\text { Drooling was reduced } \\
\text { significantly }(p<.05) \text {. }\end{array}$ \\
\hline $\begin{array}{l}\text { Russo et al. } \\
\text { [16] }\end{array}$ & $\begin{array}{l}\text { IV } \\
\text { (Withdrawal } \\
\text { design) }\end{array}$ & 22 CP (5 to 15 years) & $\begin{array}{l}\text { (Muscle vibration) The } \\
\text { training was } 3 \text { days long } \\
\text { and was repeated three } \\
\text { times each day. Each } \\
\text { application took ten } \\
\text { minutes to complete, } \\
\text { with a } 60 \text {-s gap between } \\
\text { each of the three appli- } \\
\text { cations } 10 \text { days. }\end{array}$ & & $\begin{array}{l}\text { Drooling by } \\
\text { DIS, DFSS, VAS, } \\
\text { and DQ }\end{array}$ & $\begin{array}{l}\text { Statistically significant } \\
\text { differences between base } \\
\text { line and ( } 10 \text { days, } \\
1 \text { month and } 3 \text { months) } p \\
<0.001 \text { in all scales. No } \\
\text { statistically significant } \\
\text { differences between } 10 \\
\text { days to } 1 \text { month, } 10 \text { days } \\
\text { to } 3 \text { months, and } 1 \\
\text { month to } 3 \text { months in all } \\
\text { scales. }\end{array}$ \\
\hline $\begin{array}{l}\text { lammatteo } \\
\text { et al. [30] }\end{array}$ & $\begin{array}{l}\text { IV } \\
\text { (Withdrawal } \\
\text { design) }\end{array}$ & $\begin{array}{l}2 \mathrm{CP} \text { (first subject } 2 \\
\text { years and } 7 \text { months } \\
\text { and the other subject } \\
2 \text { years and } 11\end{array}$ & $\begin{array}{l}\text { Oral facilitation } \\
\text { techniques: Treatment } \\
\text { took place over } 12 \text { days } \\
\text { of intervention. }\end{array}$ & & $\begin{array}{l}\text { Drooling by } \\
\text { an OHAUS } 700 \\
\text { series triple } \\
\text { balance }\end{array}$ & $\begin{array}{l}\text { Decreasing drooling for } \\
\text { both participants: } \\
\text { participant } 1 \\
\text { nonsignificant, participant }\end{array}$ \\
\hline
\end{tabular}


Table 1 Summarizes the characteristics of included studies (Continued)

\begin{tabular}{|c|c|c|c|c|c|c|}
\hline \multirow[t]{2}{*}{ Study } & \multirow{2}{*}{$\begin{array}{l}\text { Level of } \\
\text { evidence, } \\
\text { study } \\
\text { design }\end{array}$} & \multirow[t]{2}{*}{ Participants } & \multicolumn{2}{|l|}{ Intervention } & \multirow{2}{*}{$\begin{array}{l}\text { Outcome of } \\
\text { interest }\end{array}$} & \multirow[t]{2}{*}{ Results } \\
\hline & & & Treatment & Control & & \\
\hline & & months) & & & $\begin{array}{l}\text { Speech by } \\
\text { tape recorder }\end{array}$ & $\begin{array}{l}2 \text { statistically significant. } \\
\text { Not increasing bilabial } \\
\text { vocalization }\end{array}$ \\
\hline $\begin{array}{l}\text { Domaracki } \\
\text { and Sisson } \\
\text { [31] }\end{array}$ & $\begin{array}{l}\text { IV } \\
\text { (withdrawal } \\
\text { experimental } \\
\text { design) }\end{array}$ & $\begin{array}{l}2 \text { subjects, both } 10 \\
\text { years }\end{array}$ & $\begin{array}{l}\text { Hourly treatment of oral } \\
\text { motor stimulation, then } \\
\text { vibration for } 10 \mathrm{~s}\end{array}$ & & $\begin{array}{l}\text { Drooling by } \\
\text { momentary } \\
\text { time sampling } \\
\text { procedure }\end{array}$ & $\begin{array}{l}\text { Decreasing drooling by } \\
\text { oral motor stimulation } \\
\text { but vibration did not } \\
\text { have additional } \\
\text { therapeutic effects when } \\
\text { applied. }\end{array}$ \\
\hline
\end{tabular}

KCPS Karaduman Chewing Performance Scale, TTRS Tongue Thrust Rating Scale, BPFAS Behavioral Pediatrics Feeding Assessment Scale, DSFS Drooling Severity and Frequency Scale, DIS Drooling Impact Scale, VAS Visual Analogue Scale, DQ drooling quotient, RCT randomized controlled trials, FUCT Functional Chewing Training, $\mathrm{CP}$ cerebral palsy

one study had a score of 7 [29], one study received a perfect score of 6 [16]; and one study obtained a score of 4 [28]. The score of case series studies is presented in Table 6; one study had a score of 7 [30] and the other study received a perfect score of 6 [31].

On the Cochrane risk of bias tool, the risk of bias for all studies is presented as follows: for random sequence generation, only two studies go into enough depth about the method utilized to create the allocation sequence to determine if it should produce comparable groups [26, 27]; the other five studies are unclear in description [16, 28-31]. For allocation concealment, all studies are unclear in description [16, 26-31].

Blinding of participants and personnel, only two studies describe all measures used to blind the participants $[26,31]$; the other five studies are unclear in description $[16,27-30]$. Blinding of outcome assessors, all measures used to blind study assessors are described in two studies $[26,27]$ and the other five studies are unclear in description [16, 28-31].

Incomplete outcome data assessments, all studies explain the completeness of outcome data for each main outcome [16, 26-31].

Selective reporting, explain how the authors looked into the possibility of selective outcome reporting, the item was100 percent met [16, 26-31].
The last item which is other sources of bias states any important concerns about bias not addressed in the domains mentioned in the assessment of bias in studies; four studies fulfill this item [16, 26, 27, 29] and only three studies were unclear in description [28, 30, 31].

\section{Level of evidence}

The level of evidence in each of the seven articles was evaluated in accordance with the AACPDM Treatment Outcomes Committee version 2008.

Two studies of group design were on level II [26, 27], one study of group design was on level IV [28], and the other four studies of the single-subject design were on level IV [16, 29-31] as presented in Table 1. Oromotor exercises are effective in improving drooling, but with weak evidence and not effective in improving chewing.

The existing data was not homogenous, so the current studies were analyzed using descriptive analysis. Table 1 gives a general description of all the studies that were included, including the basic study design, level of evidence, characteristics of the participants, intervention, outcome measures used, and results.

\section{Discussion}

Searching in the literature revealed low evidence of the effectiveness of OME on feeding: chewing and drooling.

Table 2 Critical appraisal by AACPDM

\begin{tabular}{lll}
\hline Criteria & Article & Inal et al. [27] \\
\cline { 2 - 3 } 1. Described and followed inclusion and exclusion criteria & Serel Arslan et al. [26] & Yes \\
2. Described intervention for the study group and for the control group & Yes & Yes \\
3. Valid and reliable outcome measures & Yes & Yes \\
4. Masked assessors & Yes & Yes \\
5. Conducted and reported suitable statistical evaluation including power calculations & No & Yes \\
6. Dropout was reported to be less than 20\% for 2-groups, balanced dropout & Yes & No \\
7. Controlled confounding variables and limited potential biases & Yes & Yes \\
\hline
\end{tabular}


Table 3 Critical appraisal by PEDro scale

\begin{tabular}{lll}
\hline Criteria & Article & Inal et al. [27] \\
\cline { 2 - 3 } 1. Eligibility standards must be met*. & Serel Arslan et al. [26] & Yes \\
2. Random allocation of participants. & Yes & Yes \\
3. Allocation that is hidden. & Yes & No \\
4. At baseline, the prognosis was similar. & No & Yes \\
5. Blinded participant. & Yes & No \\
6. Blinded therapists. & Yes & No \\
7. Blinded assessors. & No & Yes \\
8. At least one key outcome was followed up by more than 85\%. & Yes & No \\
9. Analysis of the "intention to treat." & Yes & Yes \\
10. At least one key outcome was statistically analyzed between groups. & Yes & Yes \\
11. Point estimates of variability are presented for at least one significant outcome. & Yes & Yes \\
12. Pedro score. & $8 / 10$ & $5 / 10$ \\
\hline
\end{tabular}

*This criterion is not counted for the total PEDro score

Oral-motor exercises are non-speech activities in dealing with $\mathrm{CP}$ children. One study reported that no adverse events were detected following this intervention, while the other six studies did not report it.

The small number of studies that met the inclusion criteria was the review's main limitation, meta-analysis not allowed because of different outcomes of interest, and the methodology of these research, as well as the type and duration of OME, all are different, so descriptive analysis was utilized.

In this systematic review 7 articles discussed the effect of OME on chewing and drooling, only two studies were RCTs [26, 27], three studies were quasi-experimental $[16,28,29]$ and two studies were case series $[30,31]$.

Awan et al. [37] reported a more significant reduction in drooling severity and it's impact in the group who received kinesio taping and OME as compared to the other group who received kinesio taping $p \leq .05$. Kumar et al. [21] reported a significant improvement in drooling and chewing after OME in children; this agrees with all studies which reported that OME were effective in the improvement of drooling in children with $\mathrm{CP}$.

All outcomes of studies represent the ICF component of body structure and body function only except one study by Serel Arslan et al. [26] which included outcomes representing the ICF component of activity and participation and body structure and body function, the remaining ICF component of contextual/environmental factors were not mentioned in any study.

The study by Serel Arslan et al. [26] who applied traditional oral motor exercises for 12 weeks, including active and passive exercises of tongue and lips showed no

Table 4 Critical appraisal for randomized controlled trials: JBI

\begin{tabular}{lll}
\hline Article criteria & Serel Arslan et al. [26] & Inal et al. [27] \\
\hline 1. True randomization & Yes & Yes \\
2. Concealed allocation & Unclear & Unclear \\
3. Similar at the baseline & Yes & Yes \\
4. Blinded participants & Yes & Unclear \\
5. Blinded therapists & No & No \\
6. Blinded assessors & Yes & Yes \\
7. Both groups treated identically & Yes & Yes \\
8. Complete follow-up & Yes & No \\
9. Analyzed participants in their groups & Yes & Unclear \\
10. The same way of measuring outcomes & Yes & Yes \\
11. Reliable outcome measure & Yes & Yes \\
12. Statistical analysis that is appropriate & Yes & Yes \\
13. Appropriate trial design & Yes & Yes \\
\hline
\end{tabular}


Table 5 critical appraisal for quasi-experimental studies: JBI

\begin{tabular}{llll}
\hline Article criteria & Fatima et al. [29] & Russo et al. [16] & Harris and Dignam [28] \\
\hline 1. What is the cause and what is the effect, according to the study? & Yes & Yes & Yes \\
2. Similar participants & Yes & Yes & Yes \\
3. Similar treatment to participants & Yes & No & No \\
4. Was there a control group? & No & Yes & Unclear \\
5. Multiple measurements of the outcome & Yes & Yes & Yes \\
6. Complete follow-up, described and analyzed differences & Yes & Yes & No \\
7. Measured outcome in the same way & Yes & Yes & Unclear \\
8. Reliable outcomes measure & Yes & Unclear & No \\
9. Appropriate statistical analysis & Yes & &
\end{tabular}

change was found in chewing. The study by Inal et al. [27] who applied classical oral motor exercises for 12 weeks, including active and passive exercises of the lips and tongue showed no improvement in chewing performance, drooling severity and frequency. The study by Harris and Dignam [28] who applied OME for 9 months, including sucking games, games of blowing out candles, blowing up balloons, and blowing trumpets showed improvement was $28 \%$. The study by Fatima et al. [29] who applied oral motor exercises over a period of 6 months, including techniques for sensory stimulation; face massage, tapping, stroking, brushing, and ice stimulation showed a significant reduction in drooling $p<0.05$. The study by Russo et al. [16] who applied vibration for 10 days showed statistically significant differences between baseline and (10 days, 1 month, and 3 months) $p<0.001$ in all scales and no statistical significance between 10 days to 1 month, 10 days to 3 months, and 1 month to 3 months in all scales. The study by Iammatteo et al. [30] who applied oral facilitation techniques for 12 days, including gentle stroking and firm pressure around lips and inside the mouth in the context of play showed decreasing drooling and study by Domaracki and Sisson [31] who applied hourly treatment of oral motor stimulation, then vibration for $10 \mathrm{~s}$, oral motor stimulation, including an NUK device which was used to stimulate the child's hard palate, brush the upper and lower gums, massage the center and both sides of the tongue, and make strokes to the inside of each cheek, showed decreasing drooling by oral motor stimulation, but when vibration was applied, it did not provide any additional therapeutic effects. This variation did not allow us to make a consistent conclusion about the best type and duration of OME to improve feeding.

This systematic review showed the effectiveness of OME in improving drooling, but with weak evidence while not effective in improving chewing.

Given the small number of studies and high heterogeneity among them, caution is advised when interpreting the current findings. Future research is needed to learn how to maintain the positive effect of OME throughout time and to identify the important characteristics of OME (intensity, frequency, and duration).

\section{Conclusion}

This systematic review is an attempt to close the gap in knowledge that exists between research and clinical practice in using OME in children with $\mathrm{CP}$. There is a clear need for more RCTs focusing on this issue to

Table 6 Critical appraisal for case series studies: JBI

\begin{tabular}{lll}
\hline Article criteria & lammatteo et al. [30] & Domaracki and Sisson [31] \\
\hline 1. Clear criteria for inclusion & Yes & Unclear \\
2. Reliable measure of condition & Yes & Yes \\
3. Used valid methods & Yes & Yes \\
4. Consecutive inclusion of participants & Unclear & Unclear \\
5. Participants' full participation & Unclear & Unclear \\
6. Demographic information is presented in a simple and concise manner & Yes & Yes \\
7. Clinical data must be reported in a transparent manner & Yes & Yes \\
8. Clearly stated outcomes or follow-up findings & Yes & Yes \\
9. Reporting of the presenting site(s)/clinic in detail(s) & Unclear & Unclear \\
10. Appropriate statistical analysis & Yes & Not applicable \\
\hline
\end{tabular}


establish strong evidence. The current level of evidence to support the effectiveness of OME in children with $\mathrm{CP}$ is currently insufficient. It could be concluded from the existing evidence that OMEs were effective in improving drooling. Finally, we can conclude that there is a significant gap between OMEs and research evidence.

\section{Abbreviations}

AACPDM: American Academy for Cerebral Palsy and Developmental Medicine; CP: Cerebral palsy; PEDro: Physiotherapy Evidence Database; PRISMA: Preferred Reporting Items for Systematic Reviews and Meta-analysis; RCT: Randomized controlled trial; KCPS: Karaduman Chewing Performance Scale; BPFAS: Behavioral Pediatrics Feeding Assessment Scale; TTRS: Tongue Thrust Rating Scale; DSFS: Drooling Severity and Frequency Scale; DIS: Drooling Impact Scale; VAS: Visual analogue scale; DQ: Drooling quotient; OME: Oromotor exercises; PFD: Pediatric feeding disorders; FUCT: Functional Chewing Training; ICF: International Classification of Functioning, Disability and Health; JBI: Standardized critical appraisal tools from the Joanna Briggs Institute Meta-Analysis of Statistics Assessment and Review Instrument (JBI MASTARI)

\section{Acknowledgements}

Not applicable.

\section{Authors' contributions}

RF and AF performed an electronic search, extracted data independently, and assessed the methodological quality of included studies where discrepancies between them were resolved by consultation with the third author $\mathrm{FH}$ to reach the final decision. The authors read and approved the final manuscript.

\section{Availability of data and materials}

All data generated or analyzed during this study are included in the published article.

\section{Declarations}

Ethics approval and consent to participate

Not applicable.

\section{Consent for publication}

Not applicable.

\section{Competing interests}

The authors declare that they have no competing interests.

\section{Author details}

${ }^{1}$ Berket El Sabaa Hospital, Birket El Sab, Egypt. ${ }^{2}$ Department of Physical Therapy for Pediatrics, Faculty of Physical Therapy, Cairo University, Cairo, Egypt.

Received: 22 February 2021 Accepted: 8 July 2021

Published online: 14 December 2021

\section{References}

1. Garg AX, Hackam D, Tonelli M. Systematic Review and meta-analysis: when one study is just not enough. Clin J Am SocNephrol. 2008;3:253-60.

2. Rossetti LM. Communication intervention: birth to three. Cengage Learning; 2001.

3. Yorkston KM, Beukelman DR, Strand EA, Hakel M. Management of motor speech disorders in children and adults. 3rd ed. Austin TX: Pro-ed; 2010

4. Senner JE, Logemann J, Zecker S, Gaebler-Spira D. Drooling, saliva production, and swallowing in cerebral palsy. Dev Med Child Neurol. 2004; 46(12):801-6. https://doi.org/10.1017/s0012162204001409.

5. Reilly S, Skuse D. Characteristics and management of feeding problems of young children with cerebral palsy. Dev Med Child Neurol. 1992;34(5):37988. https://doi.org/10.1111/j.1469-8749.1992.tb11449.x.
6. Blasco PA. Management of drooling: 10 years after the Consortium on Drooling, 1990. Dev Med Child Neurol. 2002:44(11):778-81. https://doi.org/1 $0.1017 /$ s0012162201002924.

7. Maggioni L, Araújo CMTD. Guidelines and practices on feeding children with cerebral palsy. J Human Growth Dev. 2020;30(1):65-74. https://doi. org/10.7322/jhgd.v30.9974.

8. Reilly S, Skuse D, Poblete X. Prevalence of feeding problems and oral motor dysfunction in children with cerebral palsy: a community survey. J Pediatr. 1996;129(6):877-82. https://doi.org/10.1016/S0022-3476(96)70032-X.

9. $\quad$ Fung EB, Samson-Fang L, Stallings VA, et al. Received 4 January 1996 Accepted 3 July 1996 Available online 2 November 2005 Feeding dysfunction is associated with poor growth and health status $n$ children with cerebral palsy. J Am Diet Assoc. 2002;102(3):361-73. https://doi.org/1 0.1016/S0002-8223(02)90084-2.

10. Goday PS, Huh SY, Silverman A, Lukens CT, Dodrill P, Cohen SS, et al. Pediatric feeding disorder: consensus definition and conceptual framework. J Pediatr Gastroenterol Nutr. 2019;68(1):124.

11. Schwemmle C, Arens C. Feeding, eating and swallowing disorders in infants and children: An overview. HNO. 2018;66(7):515-26.

12. Lefton-Greif MA, McGrath-Morrow SA. Deglutition and respiration: development, coordination, and practical implications. Semin Speech Lang. 2007;28(3):166-79. https://doi.org/10.1055/s-2007-984723.

13. Lopes PA, Amancio OM, Araujo RF, Vitalle MS, Braga JA. Food pattern and nutritional status of children with cerebral palsy. Rev Paul Pediatr. 2013; 31(3):344-9. https://doi.org/10.1590/S0103-05822013000300011.

14. Foster KD, Woda A, Peyron MA. Effect of texture of plastic and elastic model foods on the parameters of mastication. J Neuro physiol. 2006; 95:3469-79.

15. Benfer KA, Weir KA, Bell KL, Ware RS, Davies PS, Boyd RN. Food and fluid texture consumption in a population-based cohort of preschool children with cerebral palsy: relationship to dietary intake. Dev Med Child Neurol. 2015:57(11):1056-63. https://doi.org/10.1111/dmcn.12796.

16. Russo EF, Calabrò RS, Sale P, Vergura F, De Cola MC, Militi A, et al. Can muscle vibration be the future in the treatment of cerebral palsy-related drooling? A feasibility study. Int J Med Sci. 2019;16(11):1447.

17. Schwarz SM, Corredor J, Fisher-Medina J, Cohen J, Rabinowitz S. Diagnosis and treatment of feeding disorders in children with developmental disabilities. Pediatrics. 2001;108(3):671-6. https://doi.org/1 0.1542/peds.108.3.671

18. Clark HM. Neuromuscular treatments for speech and swallowing: a tutorial. Am J Speech Lang Pathol. 2003;12(4):400-15. https://doi.org/10.1044/10580360(2003/086).

19. Burkhead LM, Sapienza CM, Rosenbek JC. Strength-training exercise in dysphagia rehabilitation: principles, procedures, and directions for future research. Dysphagia. 2007;22(3):251-65. https://doi.org/10.1007/s00455-0069074-z.

20. Ottenbacher K, Scoggins A, Wayland J. The effectiveness of a program of oral sensory-motor therapy with the severely and profoundly developmentally disabled. Occup Ther J Res. 1981;1(2):147-60. https://doi. org/10.1177/153944928100100204.

21. Kumar R, Varma A, Kumar V. Role of oromotor therapy in drooling child attending ENT department. IOSR J Dent Med Sci. 2015;14(8):9-13. https:// doi.org/10.9790/0853-1508020911.

22. Arvedson J, Clark H, Lazarus C, Schooling T, Frymark T. The effects of oralmotor exercises on swallowing in children: an evidence-based systematic review. Dev Med Child Neurol. 2010;52(11):1000-13. https://doi.org/10.1111/ j.1469-8749.2010.03707.x.

23. Higgins J P T, Green S. Cochrane handbook for systematic reviews of interventions; 2011. Available from www.cochrane-handbook.org.

24. Darrah J, Hickman R, O'Donnell M, Vogtle L, Wiart L. AACPDM methodology to develop systematic reviews of treatment interventions (Revision 1.2). Milwaukee Wl: American Academy for Cerebral Palsy and Developmental Medicine; 2008

25. Moher D, Liberati A, Tetzlaff J, Altman D. Preferred reporting items for systematic reviews and meta-analyses: the PRISMA statement. Ann Intern Med. 2009;151(4):264-9. https://doi.org/10.7326/0003-4819-151-4-2009081 80-00135.

26. Serel Arslan S, Demir NUMAN, Karaduman AA. Effect of a new treatment protocol called Functional Chewing Training on chewing function in children with cerebral palsy: a double-blind randomised controlled trial. J Oral Rehab. 2017:44(1):43-50. 
27. Inal O, Serel Arslan S, AN DNUM, Tunca Yilmaz Ö, Karaduman AA. Effect of Functional Chewing Training on tongue thrust and drooling in children with cerebral palsy: a randomised controlled trial. J Oral Rehab. 2017;44(11): 843-9. https://doi.org/10.1111/joor.12544.

28. Harris MM, Dignam PF. A non-surgical method of reducing drooling in cerebral-palsied children. Dev Med Child Neurol. 1980;22(3):293-9. https:// doi.org/10.1111/j.1469-8749.1980.tb03708.x.

29. Fatima A, Mumtaz N, Saqulain G. Drooling reduction with oral motor exercises among cerebral palsied children at the National Institute of Rehabilitation Medicine: a quasi-experimental study. Annals of King Edward Medical University. 2019;25(1):77-88

30. lammatteo PA, Trombly C, Luecke L. The effect of mouth closure on drooling and speech. Am J Occup Ther. 1990;44(8):686-91. https://doi.org/1 0.5014/ajot.44.8.686.

31. Domaracki LS, Sisson LA. Decreasing drooling with oral motor stimulation in children with multiple disabilities. Am J Occup Ther. 1990;44(8):680-4. https://doi.org/10.5014/ajot.44.8.680.

32. Sackett D, Richardson W, Rosenberg W, Haynes R. Evidence-based medicine: how to practice and teach EBM. 2nd ed. New York: Churchill Livingstone; 2000.

33. Logan L, Hickman RR, Harris SR, Heriza CB. Single-subject research design: recommendations for levels of evidence and quality rating. Dev Med Child Neurol. 2008;50(2):99-103. https://doi.org/10.1111/j.1469-8749.2007.02005.x.

34. PEDro: The Physiotherapy Evidence Database (PEDro): Available at http:// www.pedro.org.au. Accessed 2019.

35. Tufanaru C, Munn Z, Aromataris E, Campbell J, Hopp L. Chapter 3: Systematic reviews of effectiveness. In: Aromataris E, Munn Z, editors. JBI manual for evidence synthesis: JBl; 2020. Available from https://synthesisma nual.jbi.global.

36. Munn Z, Barker TH, Moola S, Tufanaru C, Stern C, McArthur A, et al. Methodological quality of case series studies: an introduction to the JBI critical appraisal tool. JBI Evid Synth. 2020;18(10):2127-33. https://doi.org/1 0.11124/JBISRIR-D-19-00099.

37. Awan WA, Aftab A, Janua UII, Ramzan R, Khan N. Effectiveness of kinesio taping with oromotor exercises in improving drooling among children with cerebral palsy. T Rehabili J. 2017;1(02):21-7.

\section{Publisher's Note}

Springer Nature remains neutral with regard to jurisdictional claims in published maps and institutional affiliations.

\section{Submit your manuscript to a SpringerOpen ${ }^{\circ}$ journal and benefit from:}

- Convenient online submission

- Rigorous peer review

- Open access: articles freely available online

- High visibility within the field

- Retaining the copyright to your article

Submit your next manuscript at $\boldsymbol{\nabla}$ springeropen.com 